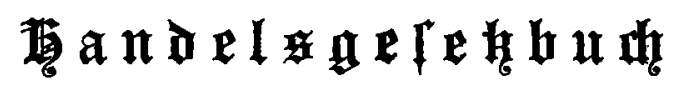
yum 10. 1897. 



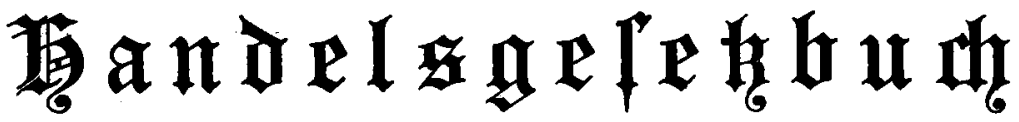

\author{
$\mathfrak{n \mathfrak { m }} 10$.
}

\section{Miit Grläuterungen}

von

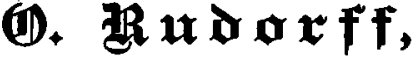

Fatb am ganfeatifen oberlanbegeride.

\section{Sfuffgaxt.}

Berlag von $\mathfrak{F e r b i n a n d ~ E n f e . ~}$ 1898. 


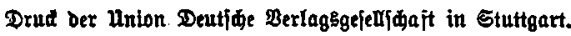

